\title{
MODEL PEMBELAJARAN PEER GROUP UNTUK PENINGKATAN KEMANDIRIAN BELAJAR MAHASISWA
}

\begin{abstract}
Anan Sutisna
Abstract

The purpose of this research is to unveil the instructional model which can strengthen the self-learning competence of the university students. A peer group instructional model is choosen as the alternative model to develop. The research findings indicate that (1) the university students' learning tends to be textbook centered based instruction and does not motivate the students to develop their learning strategy, (2) peer group instructional model can improve the students' competence in self-learning, formulating the objectives, planning the strategy, utilizing learning resources, using media, comprehending the main ideas in the learning materials, exposing ideas, understanding learning networks, and measuring learning achievement.
\end{abstract}

Key words: instruction, peer group, self-learning

\section{Abstrak}

Penelitian ini bertujuan untuk menemukan model pembelajaran yang dapat meningkatkan kemandirian belajar mahasiswa. Alternatif yang ditempuh mengembangkan model pembelajaran peer group yang berorientasi pada mahasiswa yang memiliki kemampuan lebih dari teman-teman sebayanya, untuk memberikan pengalaman belajar yang dibutuhkan oleh kelompoknya. Strategi pengembangan model pembelajaran peer group pada mahasiswa ini dilakukan dengan penelitian dan pengembangan. Hasil penelitian menunjukkan (1) situasi pembelajaran mahasiswa cenderung bersifat text book centered dan kurang memiliki kemampuan untuk melakukan improvisasi dan pengayaan strategi belajar di perguruan tinggi, dan (2) model pembelajaran peer group meningkatkan kemandirian belajar, merumuskan tujuan, merencanakan strategi, mengidentifikasi sumber belajar, mendayagunakan sumber belajar, memanfaatkan media, mengambil pokok pikiran dalam materi, menyampaikan pendapat, menyimpulkan hasil belajar, memanfaatkan media, menyampaikan ide, memahami jaringan belajar, dan mengukur keberhasilan belajar.

Kata-kata kunci: pembelajaran, peer group, kemandirian

\section{PENDAHULUAN}

Pendidikan untuk Semua (Education for All), secara konseptual merupakan suatu falsafah penyelenggaraan pendidikan yang memberikan semangat kepada semua orang agar terus belajar, tanpa pandang usia dan status yang disandangnya, serta tidak dibatasi oleh demensi ruang dan waktu (Croopley, 1987). Semua orang berhak belajar dan berkembang melalui pendidikan, baik pada jalur pendidikan formal maupun nonformal. Kegiatan pendidikan tidak terlepaskan dari proses pembelajaran yang merupakan proses pengalihan pengetahuan dan keterampilan dari dosen kepada mahasiswa. Masalah pembelajaran yang mengakibatkan mahasiswa tidak memiliki kemandirian belajar, antara lain: (1) kurang mendapatkan informasi yang jelas tentang bagaimana strategi belajar yang benar, (2) kurang memahami tentang tujuan pembelajaran, (3) kurang mendapat kesempatan untuk menentukan model dan strategi belajar, dan (4) pembelajaran selama ini kurang memberikan peluang kepada mahasiswa untuk melakukan sharing secara optimal.

Untuk mengatasi masalah di atas, diperlukan model pembelajaran yang lebih inovatif dan bahkan harus berani melakukan terobosan pembelajaran yang dapat memberikan kesempatan kepada mahasiswa untuk mengatasi masalah yang sedang dihadapi. Inovasi pembelajaran yang akan diterapkan dalam kegiatan perkuliahan evaluasi pendidikan ini adalah model pembelajaran peer group. Pembelajaran peer group ini dimaksudkan untuk meningkatkan kemandirian belajar mahasiswa sebagai komunitas pembelajar agar terjadi perubahan pada diri mahasiswa dalam setiap aktivitas belajar. Sentra pembelajaran dengan model peer group lebih menekankan pada upaya peningkatan kemandirian belajar mahasiswa dengan jalan memberikan peluang kepada mahasiswa untuk melakukan sharing tentang materi belajar. Model pembelajaran peer group diharapkan mampu 
menghasilkan mahasiswa yang mandiri. Oleh karena itu sedikitnya ada tiga landasan penting dalam pembelajaran tersebut, yaitu learning to be (belajar menjadi), learning how to learn (belajar bagaimana belajar), dan learning how to live together atau belajar bagaimana untuk hidup bersama (Harefa: 2005). Berdasarkan tiga landasan tersebut, maka kemandirian mahasiswa harus diupayakan melalui model pembelajaran peer group yaitu melalui optimalisasi peran mahasiswa dalam merancang dan melaksanakan strategi belajar secara efektif dan efisien serta sharing potensi yang ada di lingkungannya, baik di kelas maupun di masyarakat.

\section{KAJIAN PUSTAKA}

Beberapa teori yang digunakan untuk meningkatkan kemandirian belajar melalui penerapan model pembelajaran peer group ini yaitu pertama, teori kemandirian belajar. Menurut Mastuhu (2003), ada beberapa pilar pendidikan yang harus diperhatikan dalam model pembelajaran yang menurut penulis sangat tepat untuk membangun kemandirian belajar melalui model pembelajaran peer group, yaitu learning to know, learning to do, learning to be, learning to life together, and learning how to learn. Jika pendapat Mastuhu tersebut disikapi dalam satu sistem pembelajaran, maka model pembelajaran yang tepat untuk menjawabnya adalah model pembelajaran peer group, yaitu model pembelajaran yang menekankan pada aktivitas pebelajar secara optimal dengan fokus membangun kemandirian belajar mahasiswa tentang bagaimana cara belajar yang benar, efektif, efisien, atau dengan istilah pembelajaran yang bertumpu pada potensi mahasiswa belajar mandiri.

Untuk menciptakan pola pembelajaran yang sesuai dengan prinsip-prinsip pembelajaran peer group, proses belajar harus dimulai dari pemberian stimulasi kepada peserta belajar dan diakhiri dengan balikan tentang kinerja yang dicapai oleh peserta didik. Jadi belajar tidak bisa hanya diukur dari penguasaan pengetahuan saja, akan tetapi perlu dilihat kinerja atau keseluruhan penampilan peserta belajar baik yang berkenaan dengan kemampuan akademik maupun kepribadiannya. Dijelaskan lebih lanjut oleh Gagne, bahwa jenis-jenis kemampuan yang harus dipelajari oleh peserta belajar untuk memperoleh keutuhan pencapaian hasil belajar meliputi intellectual skills, verbal information, cognitive strategies, motor skills, dan attitudes (Gagne, 1985). Pemikiran tersebut di atas memberikan inspirasi kepada penulis bahwa proses pembelajaran harus bisa menghasilkan pebelajar menjadi lebih mandiri dan bukan sekedar menerima pengetahuan yang diberikan oleh tutor tetapi juga terjadi sharing antara mahasiswa dengan tutor inti.

Kemandirian belajar mahasiswa adalah merupakan kemampuan dalam mengatasi dan melaksanakan kegiatan belajar, kerajinan dan keberlanjutan belajar tanpa selalu bergantung pada keberadaan dosen di kelas. Kemandirian ini juga dapat dilihat dari keberanian mahasiswa dalam melakukan dialog dengan dosen di luar jam kuliah reguler, keberanian dalam mencari dan memperoleh sumber (resources), keberanian dan keberhasilan dalam memecahkan masalah belajar, keberanian dan kemampuan dalam berdiskusi dengan teman sejawat dan nara sumber lain untuk memecahkan masalah belajar yang dihadapi.

Untuk menciptakan suasana yang mendukung terjadinya kemandirian belajar mahasiswa, dosen harus dapat menempatkan dirinya sebagai fasilitator yang didalamnya berperan sebagai catalicator, process helper, resources linker, dan solution giver. Peran ini dosen bukan sekedar melaksanakan transfer of knowledge kepada mahasiswa tetapi lebih ditekankan pada proses transfer of learning. Di samping itu dosen juga harus belajar untuk terbuka terhadap informasi baru, menerima dan menghargai pendapat mahasiswa, fleksibel dalam berfikir dan berperilaku, menghargai pemikiran dan kreativitas mahasiswa. Memberi kebebasan secara terkendali kepada mahasiswa, memberi peluang kepada mahasiswa untuk berekspresi dan beraktualisasi melalui media dan fasilitas belajar yang ada di lingkungannya. Kemandirian belajar dalam konteks model pembelajaran peer group berdampak pada penggunaan sumber dan media belajar. Sumber dan media belajar harus memiliki tujuan (a) membebaskan mahasiswa dari pola perkuliahan yang konvensional, (b) membuka kesempatan belajar sesuai kemampuan, dan (c) membangun suatu pola pembelajaran yang membimbing mahasiswa dalam melaksanakan self directed learning, pembelajaran mandiri secara langsung (Wedemeyer: 1979).

Kedua, teori andragogi menurut Malcolm S Knowles (1979) pendidikan orang dewasa harus mengacu pada kebutuhan belajar peserta didik dengan melibatkan peserta didik sebagai subjek belajar. Pelibatan peserta didik dalam proses pembelajaran didasarkan pada kenyataan bahwa peserta didik memiliki kekayaan pengalaman (the role of the learner's experience) yang dapat dijadikan sebagai bahan pembelajaran, memilki konsep diri (the self concept) yang kuat dalam memerankan diri dalam berbagai kehidupan, memiliki kesiapan belajar yang khas (the readiness to learn) sesuai dengan 
minat dan kebutuhannya, orientasi belajar yang berbeda dengan anak kecil (orientasion to learning) sehingga diperlukan strategi pembelajaran yang sesuai dengan karakteristiknya, memilki kebutuhan akan pengetahuan (the need to know) dan motivasi (motivation).

Berdasarkan teori andragogi tersebut dapat disimpulkan bahwa pembelajaran efektif dapat dicapai apabila proses pembelajaran melibatkan aktivitas mental dan fisik peserta didik secara sungguh-sungguh dan konsisten dalam setiap tahapan pembelajaran. Menurut teori ini, orang dewasa dapat menentukan apa yang akan dipelajari, di mana dan bagaimana cara mempelajarinya, serta kapan melakukan kegiatan belajar dengan melibatkan pikiran dan perbuatannya. Implikasinya dalam pembelajaran, orang dewasa akan belajar secara efektif dengan melibatkan fungsi otak kiri dan otak kanan, menggunakan kemampuan intelek dan emosi serta dengan memanfaatkan berbagai media, metode, teknik dan pengalaman belajar yang sesuai dengan karakteristiknya.

Dalam pembelajaran orang dewasa, peran dosen sebagai fasilitator yang siap memfasilitasi mahasiswa dan memerankan dirinya sebagai partner belajar. Pola semacam ini akan menghasilkan suatu proses pembelajaran multi arah dan saling membelajarakan antara fasilitator dan peserta belajar. Proses dialog menjadi kunci utama dalam praktik pembelajaran orang dewasa dan meletakkan prinsip saling mengahargai dan mempercayai antara fasilitator dan mahasiswa. Model pembelajaran semacam ini bukan berarti tanpa disain, tetapi justru diperlukan perencanaan dan disain belajar yang sistematis sehingga akan terjadi pola interaksi yang sesuai dengan fungsinya masing-masing, yaitu dosen sebagai fasilitator belajar sedangkan mahasiswa sebagai peserta belajar. Fungsi fasilitasi yang dilakukan oleh dosen dapat berupa catalisator, process helper, resources linker, dan solution giver (Huvelock: 1988).

Dalam konsep yang paling awal, pendidikan orang dewasa adalah bagian dari kehidupan. Pendidikan tidak hanya persiapan untuk memahami hal-hal yang belum diketahui dalam kehidupan masa depan, melainkan keseluruhan kehidupan individu adalah belajar. Oleh karena itu, pendidikan dapat tidak berakhir, yang berarti bahwa pendidikan pada orang dewasa tetap terjadi dalam pembatasan kedewasaan dan kematangan. Pernyataan di atas dapat dimaknai bahwa pendidikan orang dewasa juga harus selalu memperhatikan berbagai aspek dan persoalan hidup yang dihadapi. Kehidupan orang dewasa yang dimaknai sebagai proses belajar adalah kehidupannya, maka sistem dan model pembelajaran orang dewasa dipersyaratkan untuk memperhatikan demensi kehidupan orang dewasa itu sendiri.

Menurut konsep andragogi Knowles (1984: 44-46), bahwa pembelajaran orang dewasa dirancang melibatkan sejumlah pandangan yang mengakui keterkaitan dengan kematangan pebelajar dewasa, yaitu bahwa: (1) belajar orang dewasa berpusat pada masalah (problem - centered) bukan berpusat pada isi pelajaran (content - centered); (2) belajar orang dewasa harus memungkinkan dan mendorong partisipasi aktif pebelajar; (3) belajar orang dewasa mendorong pebelajar melibatkan pengalaman masa lalu ke dalam proses, untuk menilai kembali pengalaman itu di dalam situasi dan masalah-masalah yang baru; (4) iklim belajar harus kolaboratif (instruktur dengan pembelajar, dan pebelajar dengan pembelajar); (5) perencanaan belajar dilakukan sebagai aktivitas bersama antara pebelajar dengan instruktur; (6) evaluasi dilakukan sebagai aktivitas bersama antara pebelajar dengan instruktur; (7) evaluasi diarahkan pada penilaian kembali tentang kebutuhan dan minat, dan untuk merancang ulang kembali aktivitas pembelajaran yang baru; dan (8) aktivitas belajar orang dewasa adalah pengalaman bukan "pemindahan dan penyerapan" (not "transmittal and absorption").

Sedangkan menurut Brookfield, 1983 dalam Finger dan Asun (2004: 89-90) ada enam prinsip pembelajaran orang dewasa, yakni: (1) pembelajaran orang dewasa bercirikan partisipasi sukarela, (2) pembelajaran orang dewasa terdapat saling menghargai, (3) adanya semangat kerja sama antara peserta didk dan fasilitator, (4) adanya tindakan atau refleksi konsep pragmatis yang khas, (5) terjadi pemikiran yang kritis, dan (6) belajar orang dewasa adalah mengarahkan, diri untuk berkembang, dan mengaktualisasikan diri. Maksud keenam prinsip belajar orang dewasa menurut Brookfield tersebut adalah partisipasi sukarela dalam belajar orang dewasa sejalan dengan pedagogi humanistik, di mana warga belajar terlibat menentukan kebutuhannya, langkah belajar, dan proses belajar. Saling menghargai, artinya fasilitator harus menghargai warga belajar sebagai orang dewasa yang harus serius melaksanakan belajarnya, dan pada dasarnya rnerupakan proses belajar individu. Semangat kerja sama antara fasilitator dengan peserta didik yaitu, fasilitator dan peserta didik sama-sama terikat secara kolaboratif untuk mengatasi persoalan. Tindakan atau refleksi konsep yaitu berkaitan dengan pengalaman psikologis yang membawa tindakan dan pemikiran kepada upaya-upaya perbaikan. Pemikiran kritis adalah 
merefleksikan pengalaman pribadi, sehingga seseorang bisa berkembang lebih bisa mengaktualisasikan diri dan berpikir kritis.

Knowles (1984: 9-12) mengungkapkan bahwa pembelajaran orang dewasa ditekankan berdasarkan asumsi-asumsi yang membedakannya dengan pendekatan lain, yakni: (1) terkait dengan konsep warga belajar, bahwa orang dewasa adalah orang yang mampu belajar secara mandiri (seff-directed learning); (2) terkait dengan peran pengalaman belajar, dijelaskan bahwa orang dewasa memasuki aktivitas pendidikan baik dengan pengalaman yang lebih besar, maupun kualitas pengalaman yang berbeda dari orang muda; (3) terkait dengan kesiapan belajar, diasumsikan bahwa orang dewasa siap untuk belajar jika mereka mengalami suatu kebutuhan untuk mengetahui atau melakukan sesuatu, agar mereka dapat menampilkan aspek-aspek kehidupan yang lebih baik; (4) terkait dengan orientasi belajar, mengingat orang dewasa termotivasi untuk belajar setelah mengalami suatu kebutuhan dalam situasi kehidupan mereka, mereka memasuki suatu aktivitas pendidikan dengan orientasi terpusat pada kehidupan, terpusat pada tugas, atau terpusat pada pemecahan masalah untuk belajar; (5) terkait dengan motivasi belajar, sekalipun diakui bahwa orang dewasa akan merespon terhadap beberapa motivasi eksternal (misalnya pekerjaan yang lebih baik, peningkatan gaji) dan motivasi internal, yaitu keyakinan diri, pengakuan, kualitas hidup yang lebih baik, kepercayaan diri yang lebih besar, aktualisasi diri.

Ketiga, teori belajar partsisipatif. Sudjana (2005: 155) mendefinisikan bahwa pembelajaran partisipatif adalah upaya pendidik untuk mengikutsertakan peserta didik dalam kegiatan pembelajaran. Kegiatan pembelajaran partisipatif mengandung arti ikutsertanya peserta didik di dalam program pembelajaran, yang diwujudkan dalam tiga tahapan kegiatan pembelajaran, yaitu perencanaan program (programplanning), pelaksanaan program (program implementation), dan penilaian (program evaluation) kegiatan pembelajaran. Definisi tersebut tersebut mencerminkan adanya upaya untuk terjadinya keterlibatan peserta dalam setiap tahapan pembelajaran, yaitu keterlibatan pebelajar mulai dari tahap perencanaan (identifikasi kebutuhan dan penyusunan tujuan), penetapan program kegiatan pembelajaran, pelaksanaan program kegiatan pembelajaran, dan evaluasi program pembelajaran. Keterlibatan pebelajar tersebut sebagai bentuk partisipasi pebelajar.

Selanjutnya Sudjana (2000: 155-157) menjelaskan bahwa: (1) partisipasi pada tahap perencanaan, merupakan keterlibatan mahasiswa dalam kegiatan mengidentifikasi kebutuhan belajar, permasalahan dan prioritas masalah, sumber-sumber atau potensi yang tersedia dan kemungkinan hambatan dalam pembelajaran; (2) partisipasi pada perumusan tujuan belajar, adalah keterlibatan mahasiswa merumuskan tujuan belajar; dan (3) partisipasi pada tahap pelaksanaan program kegiatan pembelajaran, berupa keterlibatan mahasiswa dalam menciptakan iklim yang kondusif dalam belajar. Iklim kondusif yang dimaksudkannya meliputi: (a) kedisiplinan mahasiswa yang ditandai dengan keteraturan dalam kehadiran pada setiap kegiatan pembelajaran, (b) pembinaan hubungan antar sesama mahasiswa, dan mahasiswa dengan dosen sehingga tercipta hubungan yang terbuka, akrab, terarah, saling menghargai, saling membantu dan saling belajar, (c) interaksi kegiatan pembelajaran antara mahasiswa dengan dosen dilakukan secara horizontal, yang menggambarkan terjadinya komunikasi yang sejajar baik antara mahasiswa dengapengajar, maupun antar mahasiswa, dan (d) kegiatan pembelajaran berpusat pada mahasiswa bukan pada pengajar, artinya menekankan pada peran mahasiswayang lebih aktif melakukan kegiatan pembelajaran, bukan terletak pada pengajar yang mengutamakan kegiatan mengajar.

Sudjana (2000: 172-174), menyatakan bahwa pembelajaran partisipatif terdiri dari empat prinsip yaitu bahwa pembelajaran partisipatif: (1) didasarkan pada kebutuhan belajar (learning needs based); (2) kebutuhan belajar sebagai landasan untuk penyusunan dan pengembangan program kegiatan pembelajaran partisipatif, sehingga kebutuhan belajar menjadi salah satu faktor penting dalam pembelajaran partisipatif; (3) berorientasi pada tujuan kegiatan pembelajaran (learning goals and objective oriented); (4) pembelajaran partisipatif direncanakan dan dilaksanakan untuk mencapai tujuan pembelajaran yang ditetapkan sebelumnya berdasarkan kebutuhan belajar mahasiswa; (5) berpusat pada mahasiswa (participant centered), prinsip ini mengandung makna bahwa kegiatan pembelajaran yang dilakukan, harus didasarkan dan disesuaikan dengan latar belakang kehidupan mahasiswa; dan (6) berangkat dari pengalaman belajar (experiential learning), kegiatan pembelajaran partisipatif disusun dan dilaksanakan bertitiktolak dari hal-hal yang telah dikuasai mahasiswa atau dari pengalaman yang telah dikuasai mahasiswa.

Keempat, teori pembelajaran peer group ini dapat diartikan sebagai proses pengalihan pengetahuan 
dan keterampilan melalui pemanfaatan dinamika kelompok dalam meningkatkan kemandirian belajar mahasiswa. Dalam hal ini tutor kelas belajarnya adalah teman sebaya (peer group). Dalam penelitian yang akan dilakukan nanti, strategi pembelajaran berpusat pada keaktifan dan dinamika kelompok teman sebaya (peer group) tersebut atas pengendalian dan pengawasan dosen sebagai fasilitator.Dengan demikian, berhasil atau tidaknya kegiatan pembelajaran tersebut tentu saja akan bergantung pada ada atau tidaknya dinamika kelompokitu. Adapun bentuk kegiatan yang akan dilaksanakan adalah sesuai tahapan-tahapan dalam kegiatan pembelajaran mulai dari merumuskan tujuan, memilih materi pelajaran, menentukan metode, menyusun strategi pembelajaran, mengelola kelas, dan melakukan evaluasi. Prosedur dalam pembelajaran peer group ini ialah dengan memilih dan melatih satu orang peserta didik yang diambil dari kelompok belajar tersebut yang dianggap potensial, lebih baik, dan mampu dari anggota kelompok yang lain untuk menjadi tutor dan sekaligus melaksanakan kegiatan pembelajaran dalam kelompok belajarnya.

Pengertian peer group adalah kelompok teman sebaya yang sukses dimana ia dapat berinteraksi (Santoso, 1999:85). Dalam kelompok teman sebaya, individu merasakan adanya kesamaan satu dengan yang lainya seperti dalam hal usia, kebutuhan dan tujuan yang dapat memperkuat kelompok itu. Di dalam peer group tidak dipentingkan adanya struktur organisasi, namun di antara anggota kelompok merasakan adanya tanggung jawab atas keberhasilan dan kegagalan kelompoknya. Dalam kelompok teman sebaya akan memungkinkan individu untuk saling berinteraksi, bergaul dan memberikan semangat, dan motivasi terhadap teman yang lain secara emosional. Adanya ikatan secara emosional dalam kehidupan peer group akan mendatangkan berbagai manfaat dan pengaruh yang besar bagi individu yang berada dalam kelompok tersebut. Dengan demikian dapat disimpulkan bahwa peer group adalah sekelompok teman sebaya yang mempunyai ikatan emosional yang kuat dan mereka dapat berinteraksi, bergaul, bertukar pikiran, dan pengalaman dalam memberikan perubahan dan peningkatan kemandirian dalam belajar.

Pembelajaran peer group dalam meningkatkan kemandirian belajar bagi mahasiswa dalam pembelajaran evaluasi pendidikan dengan teknik peer group sangatlah bermanfaat karena melalui kegiatan tersebut mereka akan saling berinteraksi antar anggota kelompok. Di samping itu mereka juga akan berusaha untuk memenuhi beberapa kebutuhan psikologis, seperti kebutuhan untuk menyesuaikan diri dengan teman-teman sebaya dan diterima oleh mereka, kebutuhan untuk bertukar pikiran dan berbagi perasaan, kebutuhan menemukan nilai-nilai kehidupan sebagai pegangan hidup, dan kebutuhan untuk menjadi lebih mandiri. Dalam suasana pembelajaran mereka akan merasa lebih mudah membicarakan topik atau persoalan yang mereka hadapi dalam kelompok belajarnya, di mana mereka akan dapat leluasa dan saling terbuka dalam membahas persoalan melalui bentuk diskusi yang hangat dan akrab, sehingga mereka akan dapat saling memberikan dukungan, motivasi, dan juga saling bertukar pikiran, pendapat serta pengalaman yang nantinya akan bermanfaat bagi mereka sendiri dalam mengembangkan dan meningkatkan kemandirian dalam belajar.

Kegiatan pembelajaran peer group dipandang efektif dan tepat dalam meningkatkan kemandirian belajar mahasiswa, karena dalam kegiatan tersebut terdapat bentuk interaksi dan dinamika kelompok yang akan memberikan kehidupan dan warna dalam kelompok belajar. Di samping itu melalui pembelajaran peer group, individu atau anggota kelompok akan memperoleh dan merasakan adanya: (1) interaksi dan hubungan dengan orang lain terjadinya dinamika kelompok dan (2) dukungan, motivasi dan kohesivitas dalam kelompok belajar akan semakin kuat. Dari beberapa penjelasan di atas dapat disimpulkan bahwa pembelajaran peer group dianggap efektif dalam meningkatkan kemandirian belajar mahasiswa, karena dalam pembelajaran peer group terdapat beberapa faktor yang dapat dijadikan sebagai wahana untuk meningkatkan kemandirian anggota kelompoknya, yaitu melalui interaksi dan dinamika kelompok, hubungan secara interpersonal dengan orang lain, adanya unsur motivasi, serta dukungan dan kebersamaan yang tercipta di dalam kegiatan pembelajaran peer group tersebut.

\section{METODOLOGI PENELITIAN}

Untuk mencapai tujuan penelitian ini ditempuh prosedur penelitian dan pengembangan pendidikan (educational research and development) sebagaimana yang ditulis oleh Borg dan Gall (2003). Berdasarkan guide-line Borg dan Gall tersebut ada sepuluh tahapan yang harus ditempuh dalam R \& D. Kesepuluh langkah itu secara sederhana adalah: (1) meneliti dan mengumpulkan informasi, termasuk membaca literatur, mengobservasi kelas, dan menyiapkan laporan tentang kebutuhan pengembangan; (2) 
merencanakan prototype komponen yang akan dikembangkan; (3) mengembangkan prototipe awal; (4) melakukan uji coba terbatas terhadap model awal; (5) merevisi model awal; (6) melakukan uji coba lapangan; (7) melakukan revisi produk; (8) melakukan uji coba lapangan secara operasional; (9) melakukan revisi akhir terhadap model; dan (10) melakukan diseminasi dan penyebaran kepada berbagai pihak.

Dalam penelitian ini kesepuluh langkah tersebut dimodifikasi menjadi tiga langkah pokok yaitu pertama, studi kasus dilakukan untuk mengetahui dan mendalami model-model pengelolaan pembelajaran di beberapa mata kuliah yang ada di Jurusan Pendidikan Luar Sekolah. Kedua, pengembangan model teoretik dilakukan dengan prosedur (a) penentuan komponen model berdasarkan informasi teoretik dan (b) validasi ahli dan praktisi. Ketiga, pengembangan perangkat dan substansi model dilakukan dengan prosedur (1) identifikasi perangkat dan isi model, (2) pengembangan perangkat dan substansi model, dan (3) validasi ahli dan uji coba perangkat model. Identifikasi perangkat dan substansi model dilakukan dengan cara menganalisis karakteristik matakuliah evaluasi pendidikan.

Tindakan pembelajaran dilaksanakan dalam setting perkuliahan di kelas pada mata kuliah evaluasi pendidikan mahasiswa Jurusan Pendidikan Luar Sekolah semester genap tahun ajaran 2010/2011. Subjek penelitian ini adalah 35 orang mahasiswa semester VII yang sedang melakukan pembelajaran mata kuliah evaluasi pendidikan di Jurusan Pendidikan Luar Sekolah FIP UNJ. Model pembelajaran peer group ditemukan dan dirancang sebagai model konsep yang akan dicobakan pada mahasiswa tersebut di atas, peneliti juga melakukan trianggulasi data dengan pelaksanaan perkuliahan lain untuk memastikan akhurasi data yang masuk kepada peneliti demi keperluan uji pengembangan model.

Data dikumpulkan dengan teknik observasi partisipatif dan wawancara dengan mahasiswa dan tutor. Observasi dilakukan terhadap setiap unjuk kemampuan mahasiwa yang telah ditampilkan dalam setiap interaksi pembelajaran peer group. Sedangkan pengumpulan data melalui dialog dilakukan mahasiswa dan fasilitator terhadap halhal yang berkenaan dengan kelebihan, keberhasilan, kegagalan dan permasalahan yang muncul dalam pembelajaran setelah dikenai tindakan. Pada tahap pengumpulan data ini peneliti dilengkapi dengan seperangkat catatan kejadian dan perkembangan mahasiswa, lembar observasi, dan panduan dialog yang berkenaan dengan perubahan perilaku dan sikap kemandirian belajar.

Pengolahan dan analisis data dalam penelitian ini berpedoman pada strategi analisis data penelitian kualitatif. Data yang masuk diolah melalui proses pengkategorian dan pengklasifikasian berdasarkan masalah yang diteliti. Analisis data dilakukan berpedoman pada pendapat Miles dan Huberman (1984:21-22), yaitu reduksi data, lampiran data, conclusion drawing/verification. Reduksi data meliputi kegiatan menyeleksi/memilah, memfokuskan, mengabstrasikan data dan mengubah data mentah menjadi informasi yang lebih bermakna. Lampiran data adalah proses menampilkan data ke dalam bentuk informasi yang lebih komunikatif, seperti menarasikan, membuat grafik, tabel, matrik, dan bagan. Conclusion drawing/veification adalah proses penyimpulan hasil penelitian sesuai dengan tujuan yang telah ditetapkan.

\section{HASIL DAN PEMBAHASAN}

\section{Situasi Pembelajaran}

Hasil penelitian ini menunjukkan bahwa proses perkuliahan belum menghasilkan pembelajaran yang mendorong terbentuknya mahasiswa sebagai subjek belajar dan dosen sebagai fasilitator belajar. Hal ini dapat dilihat dari beberapa fakta berikut ini (1) mahasiswa tidak mampu dan tidak mau belajar sendiri ketika tidak diberi tugas oleh dosen; (2) ketika dosen berhalangan hadir di kelas, mahasiswa tidak mampu belajar secara mandiri walaupun telah tersusun rencana kuliah semester untuk dipelajari oleh mahasiswa; (3) proses pembelajaran selama ini belum menghasilkan perubahan sikap, perilaku, dan wawasan belajar mahasiswa yang aktif dan mandiri karena masih terikat oleh tugas terstruktur dosen; (4) tidak terjadi perubahan perilaku belajar yang mendorong terbentuknya kreativitas, kemandirian, dan keberlanjutan belajar mahasiswa sebagaimana yang dipersyaratkan dalam iklim belajar di perguruan tinggi; (5) mahasiswa kurang memiliki kemampuan dan kemauan menelaah bahan pembelajaran, sehingga dalam mensikapi pembelajaran hanya sebagai pemenuhan kewajiban belaka tanpa disertai pemahaman kritis; (6) mahasiswa kurang memahami tujuan pembelajaran dari tiap pokok bahasan yang disajikan dosen dan hanya belajar jika akan diadakan tes; (7) mahasiswa tidak memiliki kekayaan strategi belajar yang relevan untuk mengatasi persoalan akademik di kampus maupun di lingkungannya; (8) mahasiswa tidak mampu melakukan belajar dengan baik karena tidak tahu bagaimana cara belajar yang baik di lingkungan perguruan tinggi; (9) model 
belajar mahasiswa cenderung bersifat text book centered dan tidak memiliki kemampuan untuk melakukan improvisasi dan pengayaan strategi belajar yang dapat menghasilkan kekayaan akademik sesuai dengan prinsip dan tuntutan belajar di perguruan tinggi; dan (10) mahasiswa cenderung meniru pekerjaan temannya ketika mendapat tugas yang harus dikerjakan di rumah, sehingga hasil pekerjaannya pun tampak seragam dan tidak mencerminkan proses belajar yang mandiri.

Hasil analisis dapat disimpulkan, bahwa beberapa persoalan pembelajaran yang mengakibatkan mahasiswa tidak memiliki kemandirian belajar antara lain: (1) mahasiswa kurang mendapatkan informasi yang jelas tentang bagaimana strategi belajar yang benar di perguruan tinggi khususnya di Jurusan Pendidikan Luar Sekolah, (2) mahasiswa kurang mendapat pemahaman tentang filosofi pembelajaran di perguruan tinggi yang memiliki karakteristik berbeda dengan pembelajaran di sekolah, (3) mahasiswa kurang mendapat peluang yang luas untuk melakukan improvisasi dan pengayaan dalam menentukan model dan strategi belajar sesuai dengan karakteristik yang dimiliki, dan (4) model pembelajaran yang selama ini diterapkan ternyata kurang memberikan peluang kepada mahasiswa untuk melakukan improvisasi belajar secara optimal dengan sistem interaksi multiarah terhadap berbagai sumber belajar sehingga tidak menghasilkan mahasiswa yang mandiri.

\section{Aspek-aspek Pembelajaran}

1. Kemandirian Belajar Merumuskan Tujuan Pembelajaran

Keterlibatan mahasiswa dalam aspek merumuskan tujuan ini masih sangat lemah. Kemampuan ini tidak muncul dengan sendirinya secara spontan, tetapi masih memerlukan stimulasi pendahuluan yang mampu mengarahkan mahasiswa untuk menghayati tujuan pembelajaran. Mahasiswa dalam proses perkuliahan ini diberikan deskripsi mata kuliah, tujuan mata kuliah, kompetensi mata kuliah dan pokok-pokok bahasan mata kuliah. Jika wawasan ini sudah dipahami oleh mahasiswa maka selanjutnya mahasiswa diberi keleluasaan dalam merumuskan tujuan mata kuliah secara mandiri. Keleluasaan waktu untuk merumuskan dan menghayati tujuan mata kuliah ini juga harus diberikan kepada mahasiswa agar mereka melakukan penelaahan kembali tujuan perkuliahan dalam waktu satu semester. Dengan demikian pada putaran berikutnya dosen memberikan pengantar tentang wawasan perkuliahan yang di dalamnya dijelaskan tentang posisi mata kuliah terhadap mata kuliah lainya dalam struktur kurikulum jurusan.

Beberapa catatan yang perlu diperhatikan dosen pembina mata kuliah adalah diperlukan kemampuan yang memadai pada diri dosen dalam mengorganisir kelas, sehingga tidak sampai terjadi salah kaprah dan lepas kendali dalam pembelajaran yang dilakukan mahasiswa. Oleh karena itu model sharing oflearning masih harus diterapkan dengan cara terpandu dan dibimbing dengan panduan tertulis yang harus dipelajari dan dipahami terlebih dahulu oleh mahasiswa. Panduan yang dipakai dalam perkuliahan ini didisain dalam bentuk kartu bacaan yang mudah dibawa, mudah dibaca, mudah didiskusikan, dan mudah disimpan. Kartu belajar juga harus menarik agar memiliki daya dorong bagi mahasiswa untuk dimanfaatkan dalam situasi apapun.

2. Kemandirian Belajar Merencanakan Strategi Pembelajaran

Strategi pembelajaran dirumuskan berdasarkan pada kemampuan diri pada aktivitas pembelajaran mandiri yang dilakukan oleh mahasiswa. Ukuran efektif dalam sistem belajar yaitu mampu menghasilkan peningkatan kapasistas mahasiswa dalam mencerna bahan belajar yang diimplementasi dalam waktu satu semester. Oleh karena itu, strategi efektif harus merujuk pada kesiapan dan kemampuan mahasiswa dalam menjalani pembelajaran yang telah tertulis dalam tujuan pembelajaran. Hasil kajian menunjukkan bahwa tidak semua mahasiswa mampu dan memiliki strategi belajar yang sesuai dengan karakterisitik dirinya dan tujuan belajar yang telah disepakati bersama. Dari jumlah mahasiswa yang mengikuti kuliah evaluasi pendidikan, hanya sebagian kecil orang yang memahami deskripsi matakuliah dan merumuskan strategi pembelajaran yang tepat.

Mahasiswa ini memiliki banyak ide tentang strategi perkuliahan yang dapat dilakukan, antara lain belajar dengan tugas terstruktur, belajar di luar kelas, belajar dengan terpandu oleh dosen, belajar kelompok, dan belajar melalui media internet. Dari seluruh data yang muncul, mengajukan model belajar kelompok dengan menggunakan sarana yang difasilitasi oleh dosen sebagai basis pembelajaran. Belajar dengan menggunakan sumber belajar melalui internet dinilai masih sangat kurang, pada model belajar semacam ini memiliki kontribusi yang besar dalam pencapaian tujuan pembelajaran. Namun demikian, bukan berarti mahasiswa selalu menginginkan sistem belajar yang inovatif. Masih banyak di antara mereka yang tetap menyenangi metode ceramah di kelas sebagai model pembelajaran yang penting dan efektif. Pendapat ini masih perlu dikaji lebih lanjut sebab diantara 
mahasiswa yang menginginkan model ini ada indikasi mereka belum memahami dengan baik tentang berbagai model pembelajaran yang saat ini terus berkembang. Oleh karena itu, penjelasan tentang strategi belajar yang efektif harus didahului dengan penjelasan serta dialog intensif mengenai modelmodel pembelajaran yang sesuai dengan karakteristik pendidikan luar sekolah.

3. Kemandirian Belajar Mengidentifikasi Sumber Belajar

Hasil analisis ditemukan bahwa kemampuan mahasiswa dalam mendayagunakan sumber belajar masih rendah dan hanya dilakukan ketika jadwal penyelesaian tugas mendekati batas akhir. Namun, hampir semua mahasiswa melakukan interaksi dengan dosen sesuai dengan tujuan yang ditetapkan sebelumnya. Sebagian besar mahasiswa masih mengandalkan dosen sebagai fasilitator dan belum berani melakukan improvisasi interaksi dengan sumber belajar selain dosen pembina mata kuliah.

Menurut mahasiswa yang belum melakukan interaksi dan belajar kepada sumber belajar lain karena tidak memahami apa yang harus didiskusikan. Mahasiswa belum memiliki kemampuan untuk memanfaatkan dan mencari sumber belajar informal yang tersebar di lingkungan masyarakat dengan cara menghubungi tokoh dan pelaku pendidikan di masyarakat. Mahasiswa belum terbiasa melakukan diskusi dengan pengelola dan pengurus Pusat Kegiatan Belajar Masyarakat, kelompok penyelenggara kursus, tokoh dan pelaku lembaga swadaya masyarakat, dan kelompok keswadayaan yang lain. Kemampuan untuk melakukan konfirmasi sebagai uji keabsahan informasi belum banyak dilakukan mahasiswa sehingga mahasiswa memiliki kecenderungan untuk selalu mempercayai informasi yang masuk kepada dirinya.

Uji informasi ini sangat penting sebab berbagai pendapat yang muncul dari beberapa narasumber masih bersifat eksperiental dan belum teruji secara akademik baik melalui forum diskusi, kajian tulis maupun publikasi. Oleh karena itu, untuk mengatasi hal ini sistem pembelajaran yang telah disepakati bersama antara dosen dengan mahasiswa dilengkapi dengan uji diskusi antar kelompok dalam forum kelas. Dalam forum ini dilakukan presentasi hasil kerja mahasiswa yang dilanjutkan dengan dialog dengan seluruh partisipan termasuk dengan dosen pembina. Hasil diskusi kelas dikemas lagi dalam bentuk karya tulis yang harus diselesaikan mahasiswa dan dikumpulkan kepada dosen pembina sebagai dokumen belajar kelas.
4. Kemandirian Belajar Mendayagunakan Sumber Belajar

Kemampuan mahasiswa dalam memanfaatkan atau mendayagunakan berbagai sumberdaya lingkungan sebagai sumber belajar, secara umum belum menunjukkan keberhasilan yang nyata. Bahwa mahasiswa belum mampu mendayagunakan potensi dan sumber belajar secara optimal. Mahasiswa masih terpaku oleh sumber yang dibawa dosen pembina walaupun telah memiliki keberanian melakukan improvisasi terhadap berbagai sumber belajar yang lain.

Di samping sumber pustaka yang tersedia di perpustakaan, mahasiswa juga belum memanfaatkan sumber belajar (asli) indegenous yang tersebar dilingkungannya masing-masing. Berbagai sumber belajar yang diangkat mahasiswa antara lain pengalaman pribadi dan keluarga, cerita rakyat dan masyarakat terdahulu, pengalaman pemimpin informal di lingkungannya, lembaga pendidikan yang tersebar di masyarakat dan pola interaksi masyarakat yang mempengaruhi perilaku belajar masyarakat.

Di samping itu, mahasiswa juga telah berani melakukan analisis tentang sistem belajar masyarakat yang dianggap merupakan implementasi dari konsep pembelajaran, misalnya sistem belajar seorang ibu dalam mengelola keluarga, mengelola ekonomi, mendidik anak dan memerankan diri sebagai ibu rumah tangga. Mahasiswa juga berupaya melakukan pengamatan terhadap pola-pola belajar masyarakat yang tidak bersistem secara struktural, misalnya belajar sambil bekerja, belajar berdasar pengalaman yang banyak dilakukan oleh masyarakat awam, belajar yang tidak dilakukan secara sengaja tetapi menghasilkan suatu karya besar dan bermanfaat bagi diri dan lingkungan.

Dari peserta matakuliah evaluasi pendidikan, mahasiswa melakukan pemanfaatan sumber belajar lingkungan sebagai media peningkatan kualitas belajarnya. Namun demikian diakui bahwa masih banyak mahasiswa yang bersikap apatis terhadap pola belajar semacam ini dan hanya menggantungkan dosen dan anggota kelompok lainnya dalam menyediakan sumber belajar. Namun hal ini bukan merupakan kegagalan dari implementasi peer group, sebab di antara keduapuluh mahasiswa tersebut mampu memberikan pengaruh terhadap situasi belajar temantemannya. Bimbingan dosen masih tetap diperlukan agar intensitas dan kuantitats mahasiswa yang pandai menafaatkan sumber belajar lingkungan terus bertambah dan lebih kreatif dalam mengelolanya. Bagaimanapun andalnya dosen sebagai seorang pakar, 
sumber belajar yang berada di lingkungan sekitar tetap merupakan aset belajar yang berharga dan akan mampu memberikan kekayaan kemampuan akademik mahasiswa yang barangkali akan melebihi kekayaan akademik dosen sebagai fasilitator belajar mahasiswa di kelas.

Untuk menunjang keberhasilan model ini pada siklus berikutnya diperlukan pendampingan, panduan, konsultatif, dan diskusi yang lebih terbuka antara dosen dan mahasiswa agar terjadi proses saling belajar yang lebih terbuka dan menghargai pendapat mahasiswa sebagai subjek belajar yang cerdas dan mandiri. Pendampingan dan panduan belajar dapat dirumuskan dalam bentuk paparan tertulis dan bisa dipelajari mahasiswa sebagai pertimbangan dalam melakukan belajar mandiri. Model pembelajaran peer group ini ternyata juga memerlukan waktu yang lebih banyak dari pihak dosen secara terbuka dan informal untuk memberikan layanan belajar kepada mahasiswa di luar jam pembelajaran.

5. Kemandirian Belajar dalam Memanfaatkan Media Pembelajaran

Dalam perencanaan perkuliahan, mahasiwa diberi kesempatan luas untuk menggali dan memanfaatkan media belajar untuk membantu peningkatan pemahaman hasil belajar. Secara umum mahasiswa sudah mampu memanfaatkan potensi lingkungan sebagai media belajar. Sebagai indikator dari keberhasilan ini dapat dilihat dari kemandirian belajar mahasiswa dalam memilih seting dan situasi belajar kelompok yang diinginkan dan yang sesuai dengan kondisi yang dihadapi. Mahasiswa sering memanfaatkan alam sekitar di lingkungan kampus sebagai media belajar, mengatur seting kelas sebagai arena belajar yang menyenangkan, memilih alat-alat yang tersedia di kelas sebagai media belajar, mengelola sumber daya yang tersedia di lingkungan kampus sebagai media belajar yang menyenangkan, seperti taman kampus, kantin, ruang terbuka dan kelas komputer.

Diperlukan kemandirian mahasiswa dalam memanfaatkan media belajar sebagai alat bantu belajar, sebab potensi, dan sumber daya lingkungan tidak selalu langsung berwujud media siap pakai, tetapi masih memerlukan penyesuaian dengan tujuan pembelajaran yang ingin dicapai. Misalnya, sumber daya dan potensi lingkungan yang berupa kelompok sosial yang tersebar di masyarakat dapat digunakan sebagai media belajar dengan melalui rekayasa berupa memberikan muatan program, disain acara, rekayasa peran masing-masing anggota, dan pencerahan terhadap visi dan misi lembaga. Dengan cara tersebut mahasiswa dapat masuk ke dalam sistem sosial dan dapat melakukan interaksi belajar sesuai dengan yang diinginkan. Masih banyak lagi potensi semacam itu yang dapat digunakan sebagai media belajar mahasiswa tanpa mengurangai kebermaknaan kelompok sosial masyarakat sebagai arena interaksi dan komunikasi anggotanya.

Pemanfaatan media belajar dalam peningkatan kualitas akademik merupakan keharusan dalam sistem pembelajaran saat ini. Jaringan belajar yang bersifat maya dari berbagai situs internet telah memberikan pengayaan akademik mahasiswa dan bahkan mempermudah proses pembelajaran. Oleh karena itu, pemanfaatan jaringan internet merupakan bagian yang tidak terpisahkan dari sistem pembelajaran peer group. Mahasiswa didorong untuk menggali informasi melalui situs internet dengan memanfaatkan sumber belajar yang ada di lingkungan kampus maupun di lingkungan sekitar.

Kinerja mahasiswa dalam memanfaatkan jaringan situs internet menunjukkan adanya peningkatan yang tinggi. Hampir setiap persoalan belajar, materi belajar dan tugas akademik yang menjdi tanggungjawabnya selalu dilengkapi dengan informasi terkini yang termuat dalam internet. Dengan cara ini diperoleh aneka ragam informasi yang mampu mendukung pengayaan dan pendalaman pemahaman mahasiswa, serta memberikan peluang untuk berdiskusi tentang informasi yang diperoleh dari internet.

6. Kemandirian Belajar Mengambil Pokok Pikiran dalam Bahan Belajar

Kemandirian belajar mahasiswa dalam mengungkap ide atau pokok pikiran yang terkandung dalam bahan belajar menunjukkan hasil yang meningkat jika dibanding dengan sebelum mengikuti model pembelajaran peer group. Peningkatan terjadi pada kemampuan memahami isi bahan belajar, mengungkap isi bahan belajar, kemampuan memilih pokok bahasan yang sesuai dengan bahasan mata kuliah evaluasi pendidikan, memahami maksud penulis dalam bahan belajar dan kemampuan dalam memilih dan mengambil simpulan dalam bahan belajar. Peningkatan kemampuan ini sangat penting sebab dalam beberapa literatur Jurusan Pendidikan Luar Sekolah tidak banyak ditemukan buku-buku yang memiliki judul persis dengan nama mata kuliah dan pokok bahasan yang akan dibahas dalam pembelajaran. Oleh karena itu, strategi pembelajaran yang perlu ditingkatkan dalam setiap matakuliah di Jurusan Pendidikan Luar Sekolah adalah kemampuan mahasiswa dalam mengelola dan memahami bahan 
belajar yang dapat diangkat sebagai bahan pengayaan akademik mahasiswa.

Kemampuan mahasiswa dalam memahami dan mengambil ide pokok dalam bahan belajar ini memerlukan waktu yang lama dan memerlukan proses dialog yang intensif. Mahasiswa sering melontarkan pernyataan dan pertanyaan tentang minimnya bahan belajar yang memiliki relevansi dengan kajian matakuliah.

Di samping itu, mahasiswa juga sering tidak melakukan pekerjaan dengan baik sehingga beberapa kali saran dan hasil kesepakatan dengan dosen tidak bisa dijalankan dengan maksimal. Menghadapi kasus semacam ini diperlukan pengecekan pekerjaan secara periodik, diskusi hasil kerja dengan teman sejawat, pengumpulan hasil belajar kepada dosen, dan pembahasan bersama antara mahasiswa dengan dosen. Langkah ini terus dilakukan berulang-ulang sampai mahasiswa memiliki kemampuan dan kemauan untuk belajar dan bekerja sesuai dengan filosofi tugas yang harus dikerjakan. Dosen dalam hal ini selalu menyediakan waktu untuk berdiskusi melayani mahasiswa walaupun juga banyak mahasiswa yang tidak memanfaatkan peluang ini.

7. Kemandirian Belajar Menyampaikan Pendapat atau Argumentasi

Keberanian menyampaikan argumentasi atau pendapat yang dilakukan mahasiswa sangat bervariasi. Beberapa faktor yang mempengaruhi mahasiswa dalam menyampaikan pendapat atau ide hasil belajar banyak ditentukan oleh penguasaan materi belajar, keberanian, kepercayaan diri, dukungan kelompok, apresiasi teman dan dosen, situasi kelas,dan media yang digunakan dan kemampuan berbahasa terutama pada penguasaan bahasa.

Sebagian besar mahasiswa masih perlu peningkatan dalam menyampaikan pendapat di forum kelas. Kendala utama yang sering muncul adalah kemampuan atau penguasaan bahasa yang masih lemah, keberanian, dan kepercayaan diri masih sangat rendah. Mahasiswa masih banyak yang takut dalam berpendapat dan tidak berani menampilkan diri secara tegas walaupun secara konsep mereka memiliki penguasaan yang memadahi. Menghadapi kenyataan ini dosen harus memberikan motivasi, membimbing, dan memandu mahasiswa untuk mengutarakan ide atau pendapat dengan cara memberikan apresiasi terhadap pendapatnya. Situasi ini sering dilakukan dosen dengan harapan akan muncul keberanian dan kepercayaan diri mahasiswa dalam berpendapat maupun argumentasi akademik yang lain.

Di samping memberikan apresiasi kepada mahasiswa, dosen juga harus cermat dalam mengatur giliran dan pemerataan berpendapat kepada mahasiswa dengan cara menunjuk langsung agar mahasiswa memberikan pendapat atau argumentasi tentang persoalan yang mucul di kelas. Strategi ini juga harus dibarengi dengan bimbingan dan tuntunan oleh dosen baik yang berkenaan dengan penggunaan bahasa akademik maupun kualitas isi (substansi) persoalan yang sedang dibahas. Kualitas pembicaraan mahasiswa seringkali kurang menjurus pada akar persoalan sehingga diskusi juga harus disiapkan terlebih dahulu oleh dosen dan dipahami oleh seluruh peserta diskusi.

8. Kemandiri Belajar Menyimpulkan Hasil Belajar

Kemandirian dalam mengungkap hasil belajar merupakan kemampuan intelektual yang harus dikuasai oleh mahasiswa. Kecerdasan dan keterampilan intelektual seseorang seringkali diukur berdasarkan kemampuan dalam memaparkan pendapat, mengungkapkanide, mengajukan persoalan, menyimpulkan sekaligus kemampuannya dalam memberikan solusi.

Dalam perspektif mahasiswa, kemampuan mengungkap dan menyimpulkan hasil belajar merupakan aspek penting yang dianggap sebagai ukuran keberhasilan belajar. Oleh karena itu, dalam bagian ini mahasiswa tampak antusias dalam menjawab dan memberikan pendapat tentang beberapa persoalan yang diajukan oleh dosen maupun teman sejawat. Keadaan ini semakin ramai jika tema dialog atau persoalan yang dibahas dikemas dalam bentuk kuis, sehingga mahasiswa merasa dinilai pendapatnya yang akan menentukan nilai akhir.

Dalam mengunakan bahasa ilmiah masih sangat rendah dan masih sering ditemukan penggunaan bahasa prokem, lokal, dan gaul yang bukan mencerminkan sebuah bahasa akademik. Penataan kalimat dan penggunaan bahasa yang lugas dan mudah dipahami juga masih perlu ditingkatkan agar kebiasaan berbahasa mahasiswa menjadi lebih baik yang pada gilirannya akan mempermudah melakukan dialog ilmiah dan penulisan karya-karya ilmiah. Kesungguhan dan kelugasan dalam berbahasa masih perlu ditingkatkan agar mahasiswa terbiasa berbicara dengan baik dan benar. Untuk itu, dalam konteks pembelajaran peer group diperlukan berbahasa yang benar sesuai dengan kaidah ilmiah dan kaidah akademik.

Kekayaan dalam penggunaan kosa kata juga masih perlu dilatihkan agar pembicaraan menjadi lebih menarik dan semakin banyak orang yang ingin mendengarkan serta melibatkan diri 
dalam pembicaraan. Dalam pembelajaran ini dosen memberikan penugasan dan pelatihan menulis melalui pembuatan karya ilmiah terstruktur yang selanjutnya dipresentasikan secara individual di dalam kelas dengan pendampingan dosen.

Secara umum peserta kuliah telah memiliki kemampuan yang memadai dalam mengungkap dan menyimpulkan hasil belajar melalui dialog di forum ilmiah. Hal ini disebabkan karena pengalaman mahasiswa dalam menghadapi situasi akademik baik dalam proses perkuliahan maupun di berbagai seminar di kampus. Kenyataan ini bisa dipahami sebab peserta mata kuliah ini adalah mahasiswa semester lima yang telah beradaptasi dengan lingkungan akademik yang serba scientis. Filososfi dan gaya belajar mereka sangat lekat dengan kehidupan akademik di kampus. Oleh karena itu, model pembelajaran peer group perlu terus ditingkatkan dan diimplementasikan dalam melakukan pembenahan dan penyesuaian sesuai karakter mahasiswa dan karakter akademik di kampus.

9. Kemandirian Belajar Memanfaatkan Media Belajar

Dilihat dari tujuan pembelajaran yang telah ditetapkan, media belajar yang digunakan dalam pembelajaran ini tentu belum memadai. Mahasiswa masih perlu menggali media belajar yang dapat digunakan untuk meningkatkan pemahamannya tentang tujuan mata kuliah evaluasi pendidikan, baik itu media belajar cetak maupun media belajar noncetak yang ada di lingkungan masyarakat. Dalam perencanaan perkuliahan, mahasiswa diberi kesempatan luas untuk menggali dan memanfaatkan media belajar untuk membantu peningkatan pemahaman hasil belajar.

Secara umum, mahasiswa sudah mampu memanfaatkan potensi lingkungan sebagai media belajar atau alat bantu belajar. Sebagai indikator keberhasilan, dapat dilihat dari kreativitas mahasiswa dalam memilih seting dan situasi belajar kelompok yang diinginkan dan yang sesuai dengan kondisi yang dihadapi. Mahasiswa sering memanfaatkan alam sekitar di lingkungan kampus sebagai media belajar, mengatur seting kelas sebagai arena belajar yang menyenangkan, memilih alat-alat yang tersedia di kelas sebagai media belajar, mengelola sumber daya yang tersedia di lingkungan kampus sebagai media belajar yang menyenangkan, seperti taman kampus, kantin, ruang terbuka dan kelas komputer.

Diperlukan keterampilan mahasiswa dalam memanfaatkan media belajar sebagai alat bantu belajar, sebab potensi dan sumber daya lingkungan tidak selalu langsung berwujud media siap pakai, tetapi masih memerlukan rekayasa, modifikasi dan penyesuaian dengan tujuan pembelajaran yang ingin dicapai. Misalnya, sumber daya dan potensi lingkungan yang berupa kelompok sosial yang tersebar di masyarakat dapat digunakan sebagai media belajar dengan melalui rekayasa berupa memberikan muatan program, disain acara, rekayasa peran masing-masing anggota, dan pencerahan terhadap visi dan misi lembaga. Dengan cara tersebut mahasiswa dapat masuk ke dalam sistem sosial dan dapat melakukan interaksi belajar sesuai dengan yang diinginkan.

10. Kemandirian Belajar Menyampaikan Ide dalam Forum Kelas

Strategi penyampaian pendapat yang dilakukan mahasiswa sangat bervariasi. Beberapa faktor yang mempengaruhi mahasiswa dalam menyampaikan pendapat atau ide hasil belajar banyak ditentukan oleh penguasaan materi belajar, keberanian, kepercayaan diri, dukungan kelompok, apresiasi teman dan dosen, situasi kelas, media yang digunakan dan kemampuan berbahasa terutama pada penguasaan kosa kata dan tata bahasa. Sebagian besar mahasiswa masih perlu peningkatan dalam menyampaikan pendapat di forum kelas.

Kendala utama yang sering muncul adalah kemampuan atau penguasaan bahasa yang masih lemah, keberanian, dan kepercayaan diri masih sangat rendah. Mahasiswa masih banyak yang takut dalam berpendapat (takut salah) dan tidak berani menampilkan diri secara tegas walaupun secara konsep mereka memiliki penguasaan yang memadahi. Menghadapi kenyataan ini, dosen harus memberikan motivasi, bimbingan dan pendampingan dalam memandu mahasiswa untuk mengutarakan ide atau pendapat dengan cara memberikan apresiasi atau pujian terhadap pendapatnya. Situasi ini sering dilakukan dosen dengan harapan akan muncul keberanian dan kepercayaan diri mahasiswa dalam berpendapat baik itu penyangkalan ide orang lain, dukungan, pemberian solusi maupun argumentasi akademik yang lain.

Di samping memberikan apresiasi kepada mahasiswa, dosen juga harus cermat dalam mengatur giliran dan pemerataan berpendapat kepada mahasiswa dengan cara menunjuk langsung agar mahasiswa memberikan pendapat atau argumentasi tentang persoalan yang mucul di kelas. Strategi ini juga harus dibarengi dengan bimbingan dan tuntunan oleh dosen baik yang berkenaan dengan penggunaan bahasa akademik maupun kualitas isi (substansi) persoalan yang sedang dibahas. Kualitas pembicaraan 
mahasiswa seringkali kurang menjurus pada akar persoalan sehingga diskusi juga terlebih dahulu harus dipahami oleh seluruh peserta diskusi.

11. Kemandirian Belajar Memahami Jaringan Belajar

Jaringan belajar dalam peningkatan kualitas akademik merupakan keharusan dalam sistem pembelajaran saat ini. Jaringan belajar yang bersifat maya dari berbagai situs internet telah memberikan pengayaan akademik mahasiswa dan bahkan mempermudah proses pembelajaran. Oleh karena itu, pemanfaatan jaringan internet merupakan bagian yang tidak terpisahkan dari sistem pembelajaran peer group. Mahasiswa didorong untuk menggali informasi melalui situs internet dengan memanfaatkan sumber belajar yang ada di lingkungan kampus maupun di lingkungan sekitar.

Kinerja mahasiswa dalam memahami dan memanfaatkan jaringan situs internet menunjukkan adanya peningkatan yang tinggi. Hampir setiap persoalan belajar, materi belajar dan tugas akademik yang menjdi tanggungjawabnya selalu dilengkapi dengan informasi terkini yang termuat dalam situs internet. Dengan cara ini diperoleh berbagai anekaragam informasi yang mampu mendukung pengayaan dan pendalaman pemahaman mahasiswa dan memberikan peluang untuk berdialog dan berdiskusi tentang informasi yang diperoleh dari jaringan situs internet.

12. Kemandirian Belajar Mengukur Keberhasilan Belajar Diri Sendiri

Kemampuan menilai atau mengukur keberhasilan belajar atas dirinya sendiri merupakan hasil belajar yang harus dicermati oleh dosen. Penguasaan atas bahan belajar dan standard kompetensi yang telah dimiliki mahasiswa harus diukur atas dasar pemahaman dan penguasaan yang dirasakan oleh mahasiswa itu sendiri. Oleh karena itu, mahasiswa diberi peluang yang luas untuk menentukan keberhasilan belajarnya dengan melalui evaluasi diri sendiri. Hasil evaluasi diri selanjutnya dianalisis lagi oleh dosen untuk menentukan tindak lanjut dan menentukan keberhasilan pembelajaran. Dosen harus memiliki sikap terbuka terhadap kritik dan saran yang diberikan mahasiswa berkaitan dengan kinerja pembelajaran yang merupakan bagian dari eveluasi yang dilakukan mahasiswa.

Hasil analisis yang telah dilakukan dapat disimpulkan bahwa kemampuan mahasiswa dalam mengukur keberhasilan belajar dirinya sendiri masih rendah. Mahasiswa cenderung menyerahkan kepada dosen untuk memberikan justifikasi atas keberhasilan dirinya dan menentukan kelulusan serta besaran nilai. Hal ini sebenarnya tidak salah jika dikaitkan dengan model pembelajaran yang bersumber pada teori behavioristik dengan mengandalkan dosen sebagai sumber. Akan tetapi dengan model pembelajaran yang berbasis pada "belajar bagaimana cara belajar" (learning how to learn) penyerahan diri sepenuhnya kepada dosen dianggap kurang relevan.

\section{Model Konseptual Pembelajaran Peer Group}

Adapun langkah-langkah dalam pengembangan model pembelajaran peer group ini secara umum melalui tahapan sebagai berikut.

1. melakukan eksplorasi terhadap pembelajaran yang dilakukan dosen dalam matakuliah evaluasi pendidikan dan studi dokumentasi terhadap data kinerja dan prestasi mahasiswa dan dosen;

2. mendalami peta konsep mahasiswa tentang Belajar dan Pembelajaran di perguruan tinggi;

3. melakukan dekonstruksi tentang konsep belajar dan pembelajaran yang ada pada diri mahasiswa;

4. melakukan konstruksi ulang tentang konsep belajar pembelajaran berdasar atas pemahaman baru mahasiswa;

5. membedah elemen-elemen pembelajaran peer group berbasis belajar kemandirian dalam perencanaan, pelaksanaan dan evaluasi pembelajaran;

5. merencanakan pembelajaran berbasis kemandirian dalam peer group dengan titik sentral mahasiswa sebagai subjek belajar dan dosen sebagai fasilitator belajar;

7. merumuskan model pembelajaran peer group untuk meningkatkan kemandirian belajar mahasiswa di perguruan tinggi;

8. analisis pendapat ahli (tim peneliti dan pembina matakuliah yang lain) untuk mendapatkan penyempurnaan;

9. melakukan uji lapangan terbatas (Implementasi dalam pembelajaran);

10. refleksi terhadap proses dan hasil implementasi model pembelajaran berdasar item-item pembelajaran model peer group;

11. revisi akhir model pembelajaran peer group untuk peningkatam kemandirian belajar mahasiswa; dan

12. merumuskan model pembelajaran peer group dalam matakuliah Evaluasi Pendidikan.

Langkah-langkah di atas merupakan prosedur kerja untuk merumuskan model baku pembelajaran. Berdasarkan kajian awal konseptual tentang model pembelajaran peer group, dapat dilihat dalam gambar di bawah ini. 


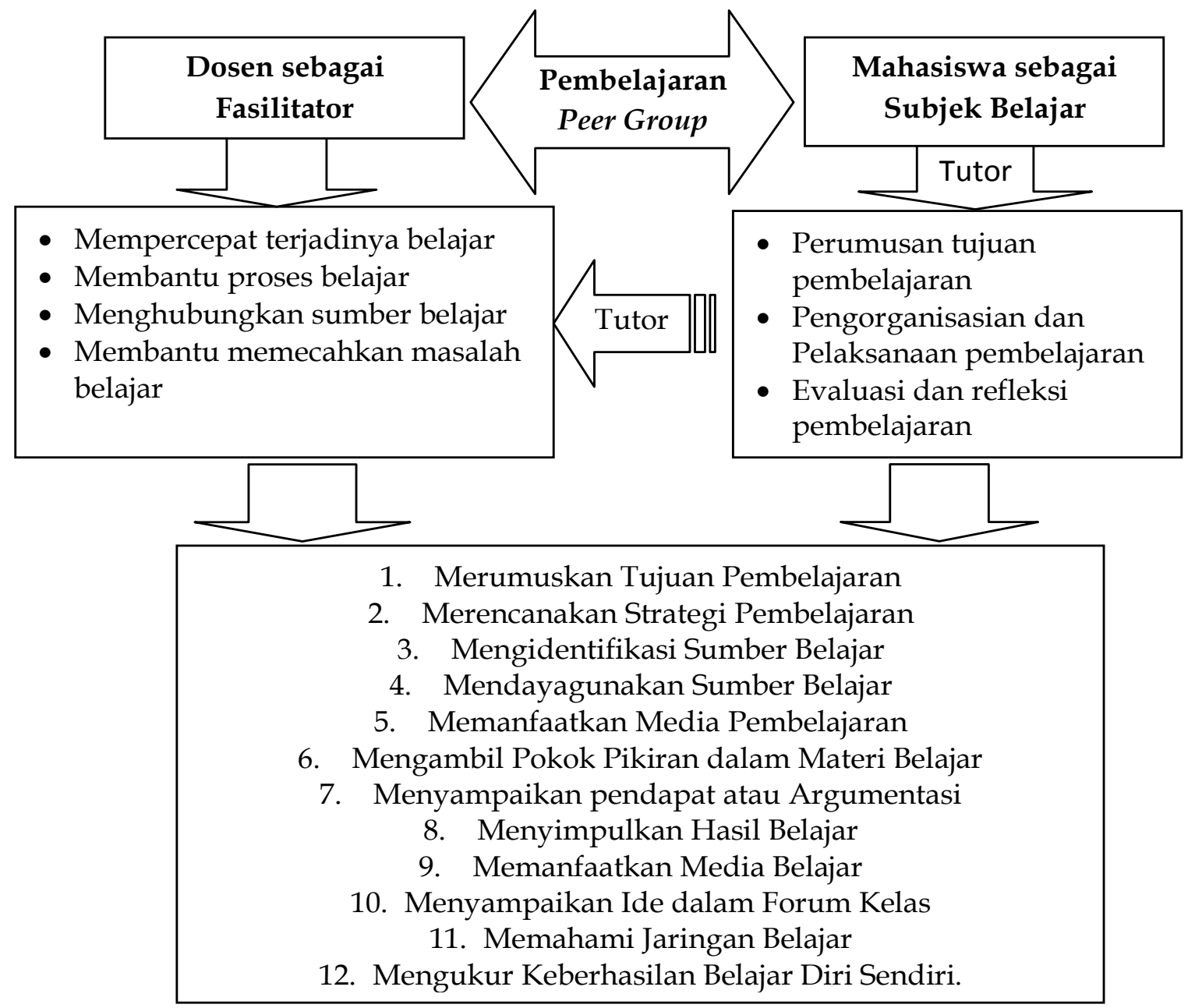

Gambar 1. Model pembelajaran peer group

Kemandirian mahasiswa dalam belajar merupakan kemampuan akademik secara perlahanlahan mulai dipahami oleh mahasiswa sebagai kebutuhan yang urgen dalam pembelajaran di perguruan tinggi. Walaupun dalam perkuliahan mahasiswa masih cenderung menunggu tugas dan saran dari dosen, namun dalam model pembelajaran peer group mahasiswa mulai menerima tugas memberikan materi perkuliahan kepada mahasiswa yang lainnya dalam satu kelompok, dengan demikian muncul kesiapan mahasiswa untuk berdiskusi dan berdialog tentang topik yang dipelajari. Pemahaman tentang peran dan kewajiban antara dosen dan mahasiswa perlu disosialisasikan terlebih dahulu sebelum model ini diimplementasikan dalam sistem pembelajaran. Hal-hal yang dapat dilakukan dosen dalam meningkatkan kemampuan mahasiswa untuk aktif membangun kemampuan akademik antara lain dengan memberikan wawasan tentang keberadaan sumber belajar yang bisa diakses mahasiswa, berdialog tentang riwayat orang sukses secara otodidak, dan peluang berprestasi dalam lingkungan kelompoknya.
Kemampuan dalam melakukan kemandirian belajar dapat terlihat pada mahasiswa yang memiliki tingkat kerajinan tinggi, aktif dalam bertanya, menjawab, dan mengerjakan tugas. Dengan demikian semangat dan kemauan mahasiswa dalam belajar mandiri merupakan kemampuan akumulatif dari kemampuan-kemampuan lain yang secara utuh tentang kecerdasan mahasiswa. Oleh karena itu untuk meningkatkan kemandirian belajar di kalangan mahasiswa perlu ditingkatkan kemampuan yang lain seperti peningkatan keberanian berpendapat, mendorong sikap kritis, berani berbuat salah dan bersedia memperbaikinya, berani mengambil keputusan, berani mengerjakan tugas belajar yang memiliki daya beda dengan mahasiswa yang lain, dan berani mencoba sesuatu yang dianggap baru.

Dalam kaitan dengan kemandirian belajar, maka motivasi bagian penting dalam pembelajaran peer group, karena motivasi akan menjadi inner power dalam meningkatkan kemandirian belajar. Mahasiswa sebagai subjek belajar diharapkan mampu membangun motivasi atas dirinya sendiri secara mandiri dan menentukan arah aktivitas belajar untuk mencapai 
hasil belajar yang telah ditentukan sebelumnya. Upaya untuk meningkatkan dan menanamkan motivasi diri mahasiswa dilakukan dengan cara memberikan pandangan dan wawasan kepada mahasiswa tentang (1) tantangan masa depan yang harus diperjuangkan mahasiswa, (2) peluang usaha dan bekerja di masa depan, (3) potensi dan kemampuan yang dimiliki mahasiswa, (4) permasalahan yang harus dihadapai dan dipecahkan mahasiswa dalam proses perkuliahan, dan (5) appresiasi dan penghargaan yang akan diperoleh mahasiswa ketika berhasil menggapai harapan hidup.

Harapan dari hasil pembelajaran yaitu munculnya perubahan pada diri mahasiswa yang berkenaan dengan strategi mahasiswa dalam meningkatkan motivasi belajar, yaitu terjadi perubahan perilaku dan motivasi belajar yang dilakukan mahasiswa dalam mengelola kegiatan belajarnya. Mahasiswa bersedia mengerjakan tugas secara mandiri, memiliki semangat dan kemauan untuk melakukan improvisasi belajar secara mandiri, bersemangat dalam mengikuti kegiatan pembelajaran, memiliki keberanian dan semangat dalam bertanya, menjawab, memberikan solusi setiap persoalan belajar, cermat dalam mengerjakan tugas, dan memiliki citacita.

Namun demikian masih banyak ditemukan mahasiswa yang selalu malas dan belum memiliki semangat untuk mengikuti kegiatan pembelajaran secara mandiri, baik ketika mengikuti kegiatan belajar di kelas maupun ketika mengerjakan tugas terstruktur di luar kelas. Sebagai komunitas yang memiliki keberagaman, tentu mahasiswa juga memiliki harapan dan cita-cita hidup setelah mereka menyelesaikan kuliah. Oleh karena itu kemandirian belajar merupakan bentuk dari hasil improvisasi belajar mahasiswa yang pada gilirannya juga akan menghasilkan kebermaknaan hidup di kemudian hari. Dalam konteks ini dosen harus tetap memberikan bimbingan dan apresiasi kepada mahasiswa agar mereka mampu membangun kebermaknaan hasil belajar sebagai modal untuk melakukan perubahan lingkungan yang mampu menghasilkan kebermanfaatan hidup bagi dirinya.

Akhirnya harus selalu disadari oleh setiap dosen bahwa tujuan akhir dari suatu pembelajaran adalah terjadinya proses pendewasaan mahasiswa dalam mengelola kemampuan intelektual dan keterampilan yang telah dimiliki untuk melakukan pengelolaan terhadap sumberdaya lingkungan agar bermanfaat untuk dirinya sendiri dan masyarakat luas. Upaya ini harus disadari sepenuhnya oleh dosen dan mahasiswa agar terjadi interaksi yang positif dalam setiap kegiatan pembelajaran diperguruan tinggi. Strategi belajar di perguruan tinggi harus dibangun dengan berlandaskan pada asas kerja sama dan saling membangun antara komponen akademik kampus. Mahasiswa harus selalu dibiasakan untuk berdialog dan berdiskusi dengan teman sejawat dan dosen mata kuliah untuk membangun pribadi akademik yang memadahi, kreatif dan peka terhadap persoalan sosial. Oleh karena itu, strategi belajar kelompok dan belajar individual harus merupakan bagian dari strategi belajar di perguruan tinggi yang harus ditanamkan kepada mahasiswa. Dalam konteks ini mahasiswa harus pandai dalam menerima pendapat orang lain, memberikan tanggapan atas pendapat orang lain, pandai menggunakan bahasa yang santun dalam standar akademik, mampu memberikan masukan dan solusi secara proporsional di lingkungan kampus, dan mampu menempatkan diri dalam sistem kelompok secara wajar tanpa dilandasi oleh upaya penguasaan otoritas secara pribadi.

\section{PENUTUP}

\section{Kesimpulan}

Pertama, situasi pembelajaran menunjukan bahwa: (1) mahasiswa tidak mampu dan tidak mau belajar sendiri ketika tidak diberi tugas oleh dosen, (2) ketika dosen berhalangan hadir di kelas, mahasiswa tidak mampu belajar secara mandiri, (3) proses pembelajaran selama ini belum menghasilkan perubahan sikap, perilaku dan wawasan belajar mahasiswa yang mandiri, (4) tidak terjadi perubahan perilaku belajar yang mendorong terbentuknya, kemandirian belajar, (5) mahasiswa kurang memiliki kemampuan dan kemauan menelaah bahan pembelajaran, (6) mahasiswa kurang memahami tujuan pembelajaran dari tiap pokok bahasan, (7) mahasiswa tidak memiliki kekayaan strategi belajar yang relevan, (8) mahasiswa tidak mampu melakukan belajar dengan baik karena tidak tahu bagaimana cara belajar yang baik, (9) model belajar mahasiswa cenderung bersifat text book centered dan (10) mahasiswa cenderung mencontoh atau mencontek pekerjaan temannya ketika mendapat tugas yang harus dikerjakan di rumah.

Kedua, aspek-aspek dalam model pembelajaran peer group meliputi (1) Merumuskan tujuan pembelajaran, (2) merencanakan strategi pembelajaran, (3) mengidentifikasi sumber belajar, (4) mendayagunakan sumber belajar, (5) memanfaatkan media pembelajaran, (6) mengambil pokok pikiran yang terkandung dalam bahan belajar, (7) menyampaikan

Perspektif Ilmu Pendidikan - Vol. 24 Th. XV Oktober 2011 
pendapat, (8) mengambil pokok pikiran yang terkandung dalam bahan belajar, (9) mengungkap dan menyimpulkan hasil belajar, (10) menyampaikan ide/hasil belajar dalam forum kelas, (11) memahami jaringan belajar (maya maupun fisik), dan (12) mengukur keberhasilan belajar dirisendiri (self evaluation).

Ketiga, model konseptual pembelajaran peer group dalam peningkatkan kemandirian merupakan suatu sistem pembelajaran yang menunjukkan bahwa peran dosen sebagai fasilitator dan mahasiswa sebagai subjek pembelajar dalam proses perkuliahan evaluasi pendidikan. Dimana peran dosen sebagai fasilitator mempunyai fungsi mempercepat terjadinya belajar (catalyst), membantu proses belajar (process helper), menghubungkan sumber belajar (resources linker) dan membantu memecahkan masalah belajar (solution helper). Sedangkan mahasiswa sebagai subjek pembelajar melalui tutor sebaya mempunyai tugas perumusan tujuan pembelajaran, pengorganisasian, dan pelaksanaan pembelajaran, serta evaluasi dan refleksi pembelajaran

Saran

Untuk meningkatan pencapaian pembelajaran yang efektif, diperlukan model pembelajaran peer group dengan asas sharing of learning dimana melalui uji penerapan terhadap mata kuliah evaluasi pendidikan di jurusan. Hal ini dimaksudkan agar diperoleh pemahaman menyeluruh tentang model pembelajaran tersebut oleh mahasiswa maupun dosen dalam mengimplementasikannya. Peranan dosen dan mahasiswa harus dipahami secara jelas sehingga masing-masing memiliki tanggung jawab dan kewajiban yang harus dilakukan dalam aktivitas pembelajaran. Segala persoalan yang muncul dari masing-masing dosen dan mahasiswa harus direkam dan selanjutnya dilakukan diskusi dalam suatu forum akademik untuk membahas persoalan dan mencari pemecahan untuk memperoleh penyempurnaan model.

Dalam konteks model pembelajaran peer group, mahasiswa diberi keleluasaan untuk berekspresi mengaktualisasikan diri dalam setiap tahap pembelajaran melalui tutor sebayanya. Sistem interaksi edukatif antara dosen dan mahasiswa dan mahasiswa dengan mahasiswa harus didasarkan pada pemberdayaan mahasiswa sehingga memiliki kemandirian dalam belajar. Untuk itu pola yang relatif baku dan memiliki kredibilitas akademik yang tinggi perlu segera dirumuskan, sehingga segala aktivitas pembelajaran dapat dipertanggungjawabkan dan diukur secara akademis.

\section{DAFTAR PUSTAKA}

Croopley, A.J. (1987). Life-long education: A psychological analysis, (terjemahan oleh Sardjan Kadir). Surabaya: Usaha Nasional.

Finger, M. \& Asun, J. M. (2004). Quo vadis pendidikan orang dewasa (Alih Bahasa:Nining Fatikasari) Yogyakarta : Pustaka Kendi.

Gall, M.D. Gall J.P. \& Borg W.R. (2003). Educational research an introduction. 7 th. Ed. Boston : Pearson Education, Inc.

Gagne, R. (1985). The conditions oflearning and theory of instruction. Fourth edition. Japan: CBS College Publishing, Holt Rinerhart and Winston, The Dryden Press.

Harefa, Andrias. (2005). Menjadi manusia pembelajar (On Becoming A Learner): Pemberdayaan Diri, Transformasi Organisasi dan Masyarakat Lewat Proses Pembelajaran. Jakarta: PT Kompas Media Nusantara.

Huberman, M.A. \& Miles, M. (1994). Qualitative Data Analysis. New York: Sage Publications Inc.

Huvelock, RG. (1988). Solving of educational problem: the theory and reality of inovation in developing countries. Paris: Unesco.

Knowles, M. S. (1986). Andragogi in Action: Applying Modern Principles of Adult Learning. San Francisco: Jossey Bass.

Knowles, M. S. (1984). Andragogy in Action: Applying Modern Principles of Adult Learning. San Francisco: Jossey Bass Inc.

Mastuhu. (2003). Menata Ulang Pemikiran Sistem Pendidikan Nasional dalam Abad 21. Jakarta: Safiria Insania Press.

Santoso, Slamet, (1999). Dinamika Kelompok, Jakarta, Bumi Aksaara

Sugiyono, (2007). Metode Penelitian Kuantitatif, Kualitatif dan $R \mathcal{E} D$, Bandung, Alfabeta.

Sudjana, D. (2005). Strategi pembelajaran dalam pendidikan luar sekolah. Bandung: Nusantara Press.

Wedemeyer, C. A. (1979). Criteria for Constructing a Distance Education System. Canadian J. Univ. Continuing Ed. VI , Hal 6 (1), 9-17.

\section{KETERANGAN PENULIS}

Anan Sutisna, lahir di Bekasi 19 April 1966. Saat ini berprofesi sebagai Dosen Jurusan Pendidikan Luar Sekolah, FIP- UNJ. 